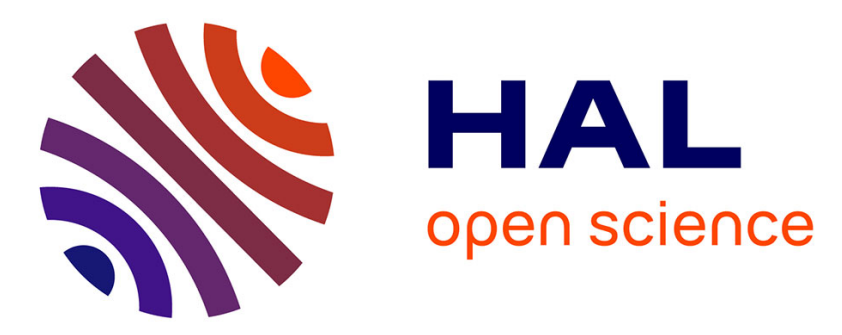

\title{
Assessing the impact of orogenic inheritance on the architecture, timing and magmatic budget of the North Atlantic rift system: a mapping approach Pauline Chenin, Gianreto Manatschal, L.L. Lavier, Duncan Erratt
}

\section{- To cite this version:}

Pauline Chenin, Gianreto Manatschal, L.L. Lavier, Duncan Erratt. Assessing the impact of orogenic inheritance on the architecture, timing and magmatic budget of the North Atlantic rift system: a mapping approach. Journal of the Geological Society of London, 2015, 10.1144/jgs2014-139 . hal01213215

\author{
HAL Id: hal-01213215 \\ https://hal.science/hal-01213215
}

Submitted on 27 Aug 2019

HAL is a multi-disciplinary open access archive for the deposit and dissemination of scientific research documents, whether they are published or not. The documents may come from teaching and research institutions in France or abroad, or from public or private research centers.
L'archive ouverte pluridisciplinaire HAL, est destinée au dépôt et à la diffusion de documents scientifiques de niveau recherche, publiés ou non, émanant des établissements d'enseignement et de recherche français ou étrangers, des laboratoires publics ou privés. 


\title{
Assessing the impact of orogenic inheritance on the
}

\section{architecture, timing and magmatic budget of the}

\section{North Atlantic rift system: a mapping approach}

\author{
Pauline Chenin*,1, Gianreto Manatschal ${ }^{1}$, Luc L. Lavier ${ }^{2}$, Duncan Erratt ${ }^{3}$ \\ ${ }^{1}$ IPGS - EOST, Université de Strasbourg, 1 rue Blessig, 67084 Strasbourg, France \\ ${ }^{2}$ Institute for Geophysics, J.J. Pickle Research Campus, Bldg. 196, 10100 Burnet Rd., Austin, Texas, \\ 78758, USA \\ ${ }^{3}$ ExxonMobil International Ltd, ExxonMobil House, Ermyn Way, Leatherhead, Surrey KT22 8UX, UK \\ * Corresponding author (email: chenin@unistra.fr)
}

\begin{abstract}
To investigate the impact of orogenic inheritance on the characteristics of the North Atlantic rift system we develop new mapping methods that highlight the first-order architecture and timing of rifts, as well as the distribution of heterogeneities inherited from the Palaeozoic Caledonian and Variscan orogenies. These maps demonstrates major differences in the behaviour of the North Atlantic rift system relative to both orogens, with the Variscan front appearing to be an important boundary. Indeed, the rift cuts through the Caledonian orogen and parallels its structural grain to the north, while it circumvents the core of the Variscides to the south. In addition, rifting is protracted and polyphase with breakup being magma-rich north of the Variscan front, as opposed to the south where a single, apparently continuous extensional event led to magma-poor breakup in less than 50 Myr. Besides, the North Atlantic rift system reactivates sutures corresponding to large $(>2,000 \mathrm{~km})$ former oceans, while sutures of small $(<500-1,000 \mathrm{~km})$ oceanic basins are little affected in both the northern and southern North Atlantic. These observations point to a major influence of orogenic inheritance on the characteristics of rift systems.
\end{abstract}




\section{Introduction}

Pre-existing orogenic structures are widely believed to exert significant controls on the development of subsequent rift systems. For example Wilson (1966) emphasized that the North Atlantic rift follows the ancient Appalachian and Mauritanian sutures, Dunbar and Sawyer (1989), Piqué and Laville (1996), Ring (1994) and Tommasi and Vauchez (2001) correlated changes in the onshore geology with along strike changes in architecture and segmentation of rifted margins, and Withjack et al. (2012) described most of Mesozoic sedimentary basins bordering the North Atlantic Ocean as formed by extensional reactivation of contractional structures from the previous Alleghanian Orogeny. However these examples are often specific and / or local and there is no general agreement on how inheritance controls subsequent extensional events. The complexity of these interactions is well-illustrated by the very different behaviour of the North Atlantic rift system with respect to the Caledonian (in the north) and Variscan (in the south) orogenic lithosphere (Figure 1). Indeed, the rift cuts through the former Caledonides and parallels its structural grain, whereas it circumvents the core of the Variscan-affected area. Furthermore, final rifting leading to breakup is magma-rich in the north, whereas it is magma-poor in the south.

The aim of this paper is firstly to map orogenic inheritance and characteristics of rift systems at the scale of the whole North Atlantic, and secondly to assess the impact of inherited structures and / or heterogeneities on the architecture, timing and magmatic budget of rift systems that went beyond the point of necking (i.e localized attenuation of the continental crust, e.g. PéronPinvidic and Manatschal (2009); Sutra et al. (2013)). We develop new mapping approaches driven by observations that highlight: (1) the distribution of major inherited features; (2) the structural architecture of rift systems; and (3) the time lag between the onset of necking and lithospheric breakup.

\section{Geological setting}

The Norwegian, Irish, Scottish and Greenland margins formed by Mesozoic rifting and Eocene breakup (Mjelde et al., 2008) of lithosphere affected by the Siluro-Devonian Caledonian orogeny (Figure 1). The Caledonides resulted from the Late Ordovician closure of the Tornquist Seaway 
and from suturing of the larger $(>3,000 \mathrm{~km}$ ) Iapetus Ocean (Torsvik and Rehnström, 2003). Note that the subduction of the Iapetus Ocean produced a magmatic arc, which is now obducted in western Norway and eastern North America (Rey et al., 1997; Roberts, 2003). The Caledonian orogen is characterized by the polyphase stacking of thin and far-travelled very extensive thrust nappes (Andersen, 1998; Rey et al., 1997). After the termination of convergence, the Caledonian range underwent extensional collapse that led to the formation of normal faults and low-angle detachment systems associated with exhumation of high pressure rocks. No significant magmatism occurred north of the Elbe lineament (Stephens, 1988; Milnes et al., 1997; Andersen, 1998), therefore remnants of the Caledonian orogenic wedge are well-preserved (Meissner, 1999).

In contrast, the Bay of Biscay and Iberian margins developed during Jurassic rifting and early Cretaceous breakup (Péron-Pinvidic and Manatschal, 2009) of lithosphere affected by the Variscan orogeny (Figure 1). The Variscides have a much more complex orogenic history than the Caledonides in that they resulted from the closure of several small $(<500-1,000 \mathrm{~km})$ immature oceanic basins - namely the Rhenohercynian, Saxothuringian and Medio-European oceanic basins - in addition to the closure of the larger $(>2,000 \mathrm{~km})$ Rheic Ocean (Matte, 2001; Mckerrow et al., 2000; Franke, 2006). Note that subduction of these immature oceanic basins failed to produce associated magmatic arcs, unlike the subduction of the Rheic ocean (Franke, 2006). Following the termination of convergence, the Variscan range underwent an orogenic collapse that led to crustal extension, formation of intramontane basins and widespread magmatic intrusion and underplating (Rey et al., 1997). This intense magmatic event was responsible for the depletion of the upper mantle (Müntener et al., 2004; Rampone, 2004), it overprinted the orogenic structures in the lower crust (Meissner, 1999; Schuster and Stüwe, 2008) and most likely welded the different parts of the orogen. 


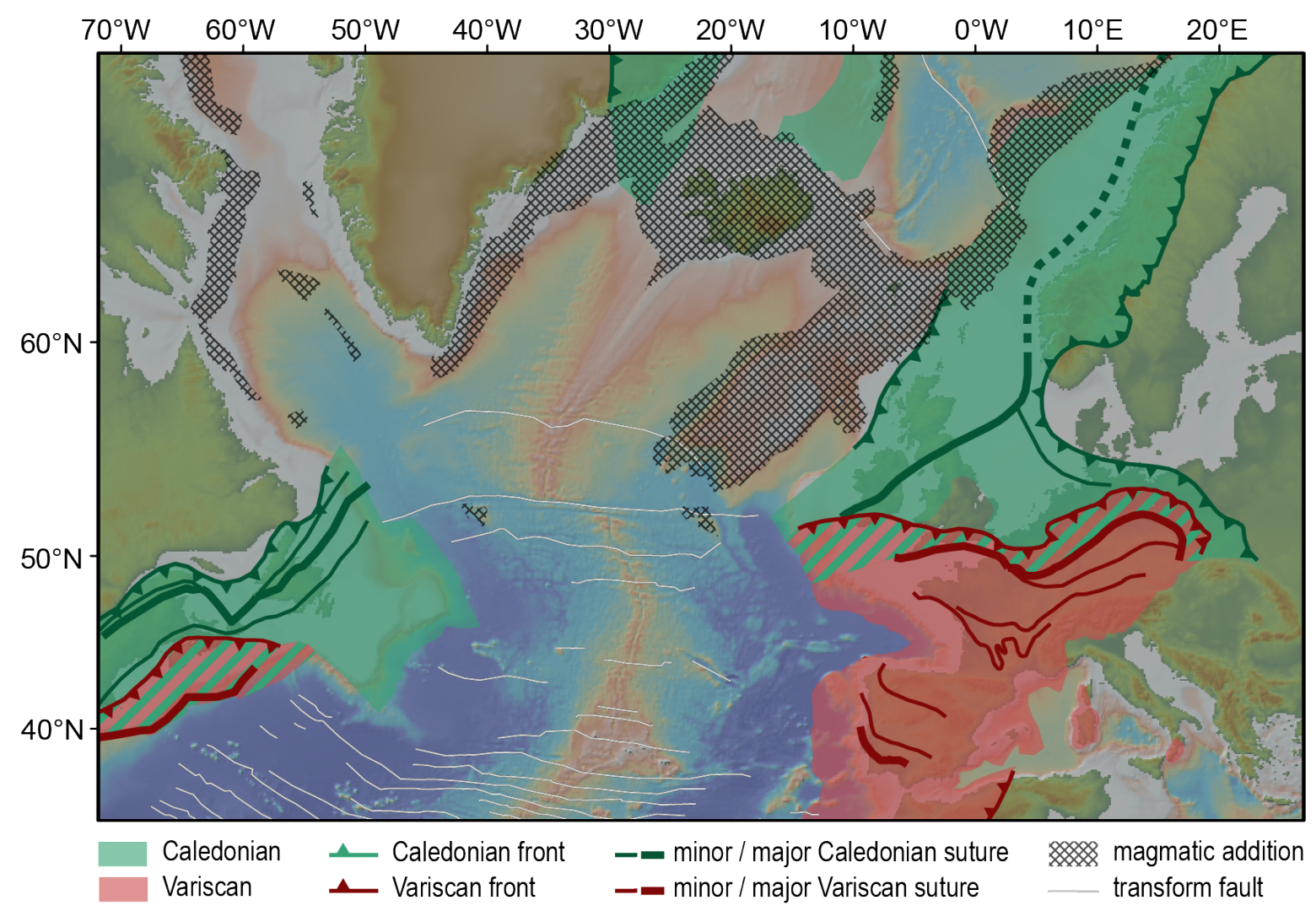

Figure 1: Overview of the main orogenic domains and associated major structures along the North Atlantic Ocean, and extent of breakup related magmatism. Sutures in North-America are after van Staal et al. (2012) and Connors and Pryer (2014) and deformation fronts after Arenas et al. (2014). See section 3.3 for references related to Europe and Greenland orogenic inheritance and magmatism extent. 


\section{Mapping inheritance}

\subsection{Definition}

We use the term inheritance to refer to the deviation between an ideal lithosphere with horizontally homogeneous physical properties ('layer-cake lithosphere') and a natural lithosphere (Figure 2 a; see also Manatschal et al., 2015 for an extended definition). Inheritance includes (1) structural complexity (faults, suture zones or mylonitic shear zones); (2) thermal lateral heterogeneities and (3) compositional heterogeneities resulting from sedimentary, tectonic, magmatic, metamorphic and metasomatic processes (for example foreland basins, magmatic arcs, intrusions, underplating, ophiolite belts, hydrated mineral phases within faults and both enriched and depleted mantle lithosphere). Note that these three types of inheritance are usually strongly interrelated and cannot be readily dissociated.

\subsection{Selection criteria and limitations}

Because of their different ages, tectonic and thermal histories (e.g. section 2), we distinguish between two main orogenic domains, namely the Caledonides and the Variscides. We define each orogenic domain as the area limited by the trace of its corresponding deformation fronts at the present-day surface (Figure $2 \mathrm{~b}$ ). Note that this location does not necessary reflect the maximum extent of the orogen since erosion may have erased part of the orogenic structures, however they remain a reasonable proxy at the scales under consideration. To limit our mapping to relevant first-order inheritance, we we consider only basin-scale features that have been preserved through time.

In western Europe, most structural heterogeneities result from the Caledonian and Variscan orogenies, therefore we select the corresponding sutures, fold-and-thrust belts and deformation fronts. Moreover, large-scale compositional heterogeneities include foreland basins, major magmatic additions as well as large-scale mantle heterogeneities.

The extent of the Variscan foreland basins is well-constrained to the north, but less so to the south where it has been extensively overprinted by the subsequent Alpine rifting and orogeny (Neubauer and Handler, 2000; von Raumer et al., 2003). The Caledonian foreland basin is likely to have had a large areal extent but, since it may not have been very thick (Cederbom et al., 2000; 

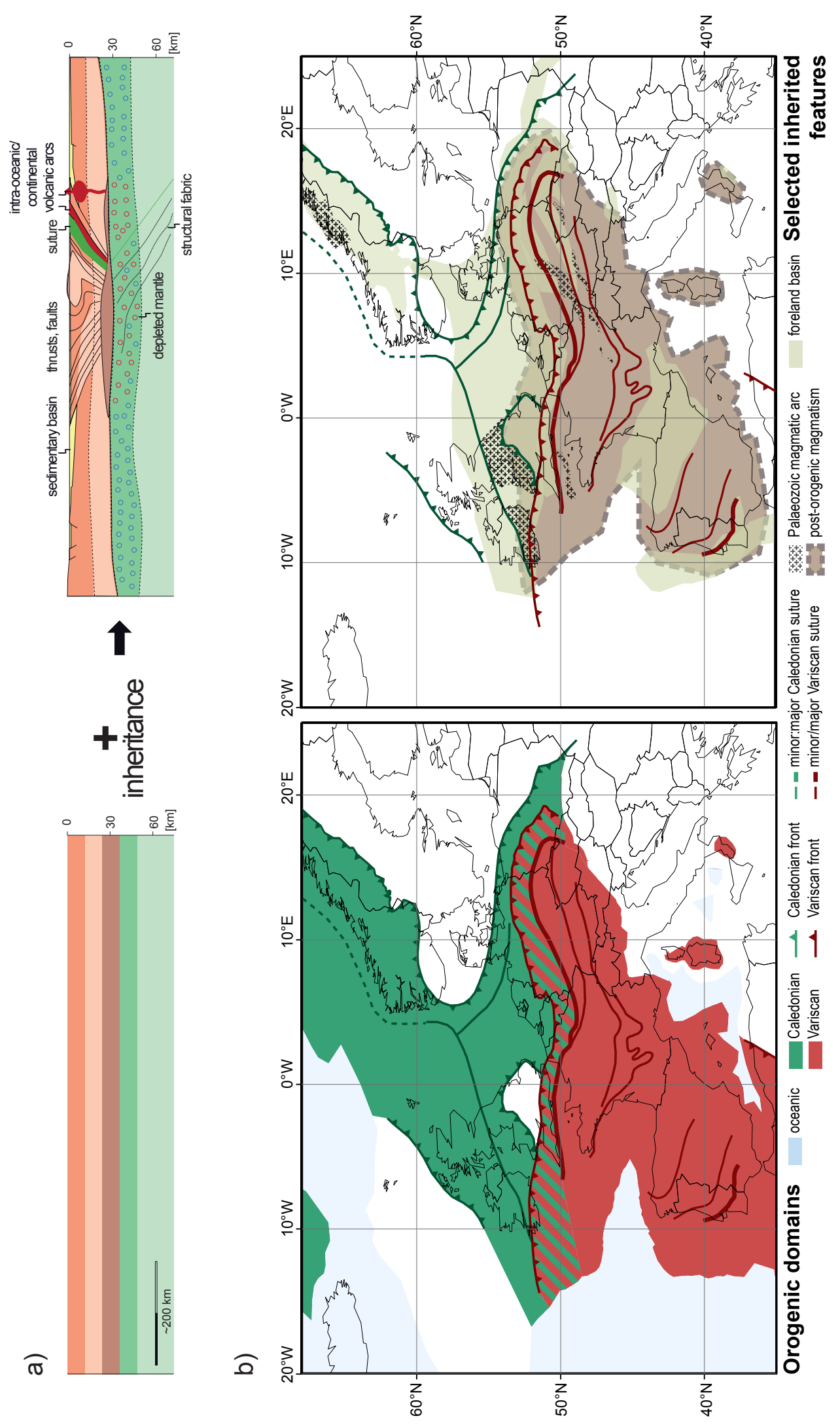

Figure 2: a) Definition of orogenic inheritance as the deviation between an ideal, horizontally homogeneous, 'layer-cake'-type lithosphere and a real, heterogeneous, lithosphere (modified after Manatschal et al., 2015); b) Maps of the main Palaeozoic and Mesozoic orogenic domains (left) and associated inheritance (right) 
Huigen and Andriessen, 2004), large parts may have been extensively eroded during Cenozoic uplift (Gee et al., 2012).

Major extrusive magmatic additions, which may reflect either pre- (volcanic arcs), syn- or post-collision (orogenic collapse) magmatic activity, have been extensively mapped over western Europe (e.g. for example Matte, 1986; Finger and Steyrer, 1990; Timmerman, 2004). Conversely, magmatic intrusions and underplating as well as mantle heterogeneities are less well defined since this requires geophysical or geochemical studies. However, ECORS seismic lines published by Bois et al. (1989) as well as the compilation of metamorphic- and magmatic-ages by Petri (2014) tend to show that the rejuvenated mafic lower crust related to post-orogenic collapse exists over the entire Variscan orogenic area (Figure $2 \mathrm{~b}$ ). Therefore we can expect large parts of the mantle underlying this domain to be depleted, as well as the overlying crust to be intruded by the resulting melts (e.g. Ivrea in northern Italy; Schaltegger and Gebauer, 1999).

As thermal heterogeneities resulting from heat transport via convection and / or advection are erased by thermal re-equilibration with the encompassing material over time $<<100 \mathrm{Myr}$ (Jaupart and Mareschal, 2007) we do not include them in our selection. Indeed, necking in the North Atlantic started approximately 100 Myr after the Variscan collapse and more than 200 Myr after the Caledonides. Alternatively, thermal heterogeneities coming from the higher concentration in radiogenic elements may last longer and merit consideration, yet such heterogeneities are usually related to the intrusion of major granitic bodies, which we have already cited as a major compositional heterogeneity (see above).

Furthermore, only features that are appropriately oriented with respect to stress direction (Ring, 1994) and within a layer stiff enough to concentrate stress differentials (Chenin and Beaumont, 2013) may have a chance of being reactivated. However, as these criteria cannot be determined a priori, we map inherited features without considering their orientation and position in-the depth domain.

\subsection{Mapping method}

Mapping of the selected inherited features described above is built on a compilation and reinterpretation of published data where available, and extrapolation based on published conceptual models where data are scarce or missing. 
We consider the suture zones and deformation fronts as mapped by Franke (2006); Ziegler and Dèzes (2006); Ballèvre et al. (2009) and Dadlez et al. (2013) for the European Variscan domain and the southern Caledonian domain. Note that the extent of the Caledonian deformation south to the Variscan front is largely uncertain (Woodcock and Strachan, 2009) and may not include the Acadian / Ardenian and Brabantian orogenic domains (Woodcock et al., 2007; Sintubin et al., 2009). Location of the suture and deformation fronts in the northern part of Norway is after Asher et al. (2001) and Mosar (2003), respectively, and the Variscan deformation front in northern Africa is from Frizon de Lamotte et al. (2011). The location of the Variscan foreland basin is after Franke and Engel (1988) and Ziegler (1988); the Caledonian foreland is mapped after Larson et al. (1999). Palaeozoic magmatic arcs are mapped after Edel et al. (2013) and Roberts (2003). Collapse-related intrusions and underplating are assumed to be present under the whole Variscan orogen as proposed by Petri (2014), as well as depleted mantle, which was the source of this magmatic event (Müntener et al., 2004; Rampone, 2004).

\subsection{Inheritance map: highlights}

The map resulting from the compilation of these published data and models is presented on Figures 1 and $2 \mathrm{~b}$ and highlights the following: (1) the North Atlantic rift follows the sutures left by the closure of the large Iapetus (Caledonian) and Rheic (Variscan) Oceans; (2) conversely, the rift abandons the sutures corresponding to the smaller Caledonian Tornquist Seaway (after a phase of extension, which formed the Central Graben, e.g. section 4) and avoids those corresponding to the Variscan Rheno-Hercynian, Saxo-Thuringian and Medio-European oceanic basins.

\section{Mapping rift domains}

\subsection{Definition}

In order to highlight rift architecture we define three first-order domains (Figure 3 a) as a function of their lithology (i.e. continental crust, oceanic crust or mantle), their crustal thickness and the amount and type of extensional deformation (e.g. Lavier and Manatschal (2006) for definition and extended discussion of rift deformation modes). In order to limit our mapping to the firstorder architecture defined with criteria as robust as possible, we use a simplification of the 
methodology developed by Sutra et al. (2013) and Tugend et al. (2014).

On the one hand, the proximal domain is made of un- or barely thinned ( $~ 30 \mathrm{~km}$ thick) continental crust and flat Moho. In this area, deformation is limited to, at most - the socalled stretching mode (Lavier and Manatschal, 2006). On the other hand, the oceanic domain corresponds to the homogeneous $\sim 6$ to $7 \mathrm{~km} / \sim 2$ sTWT thick oceanic crust resulting from steady-state seafloor spreading after the onset of the so-called magmatic mode (e.g. Manatschal et al., 2015). Between these two lightly deformed domains, the distal domain encompasses most of the strain associated to rifting. It is comprised of more or less thinned continental crust and potentially of exhumed mantle and / or magmatic addition. It includes (Figure 3 a) the necking domain, the coupled (also called hyperextended, e.g. Doré and Lundin, 2015) domain and the exhumation domain as defined by Sutra et al. (2013), however mapping marginal domains with such an accuracy is beyond the scope of this study and requires development of further techniques.

\subsection{Mapping method and limitations}

The limit between the proximal domain and the distal domain corresponds to the necking point, a more or less abrupt thinning of continental crust (Péron-Pinvidic and Manatschal, 2009). The resulting deepening of top basement and shallowing of the Moho, which are usually well-imaged both on refraction and reflection seismic sections (Mooney and Brocher, 1987), translates into a significant creation of total accommodation space (e.g. Sutra et al., 2013). However, these data are scarce and very local with regard to the scale of our mapping. In this sense, gravimetric analysis is a useful independent method revealing the necking zone and allowing its correlation between seismic sections (Murray et al., 1989). We use the Bouguer anomaly of the World Gravity Map (The International Gravimetric Bureau, 2012), which we filter passing wavelengths $<200 \mathrm{~km}$ and removing wavelengths $>400 \mathrm{~km}$ in order to highlight local-scale events such as a necking zone with respect to large-scale Moho depth variations. Importantly, care should be taken to reconcile differences between predicted present-day Moho (corresponding to top $3.3 \mathrm{~g} . \mathrm{cm}^{-3}$ peridotite) and top serpentinized peridotite as frequently observed on reflection seismic data.

The limit between the distal domain and the oceanic domain corresponds to the onset of steady state oceanic crust, which is commonly well-imaged on seismic sections as a regular 6 - 
a)
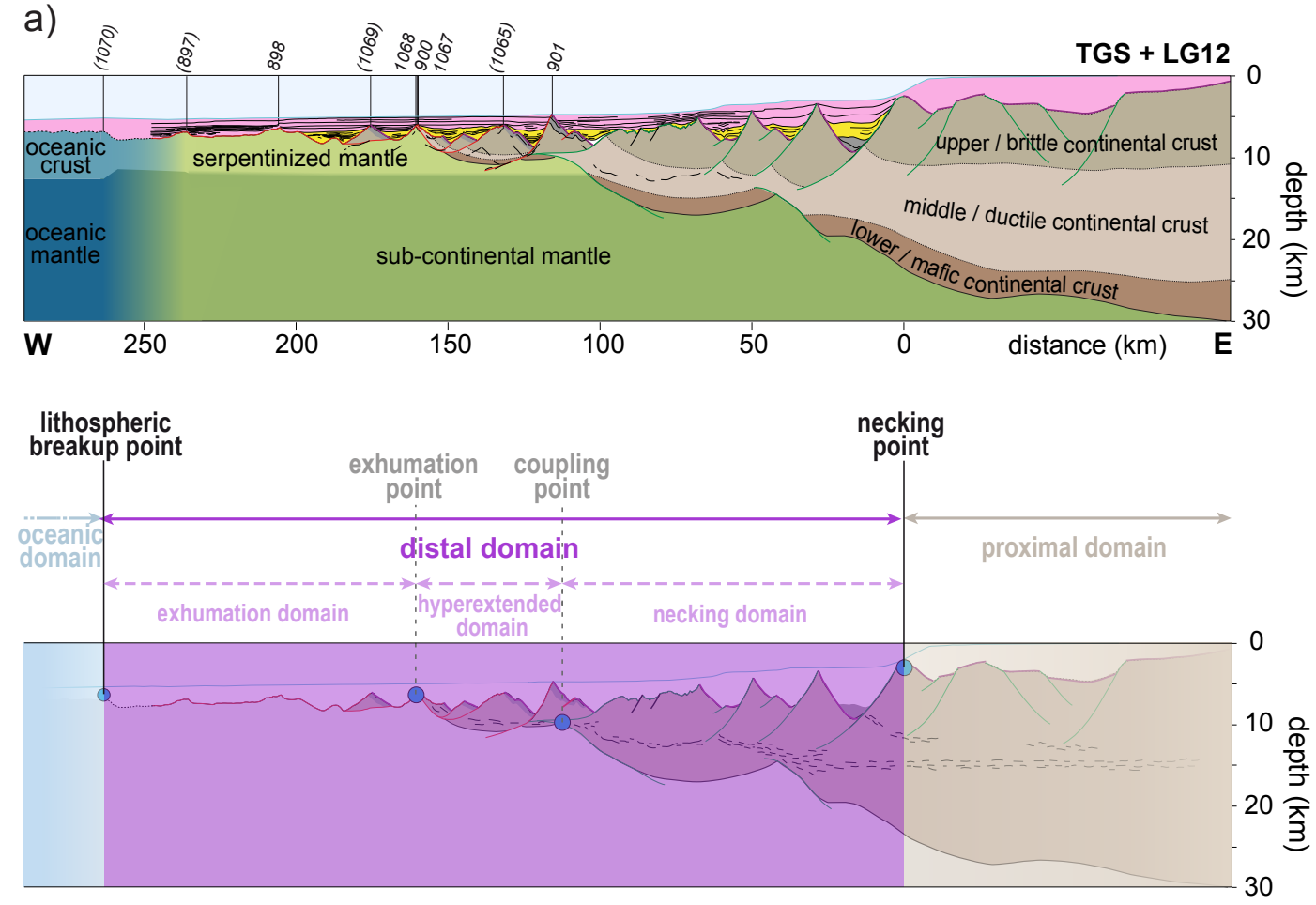

b)

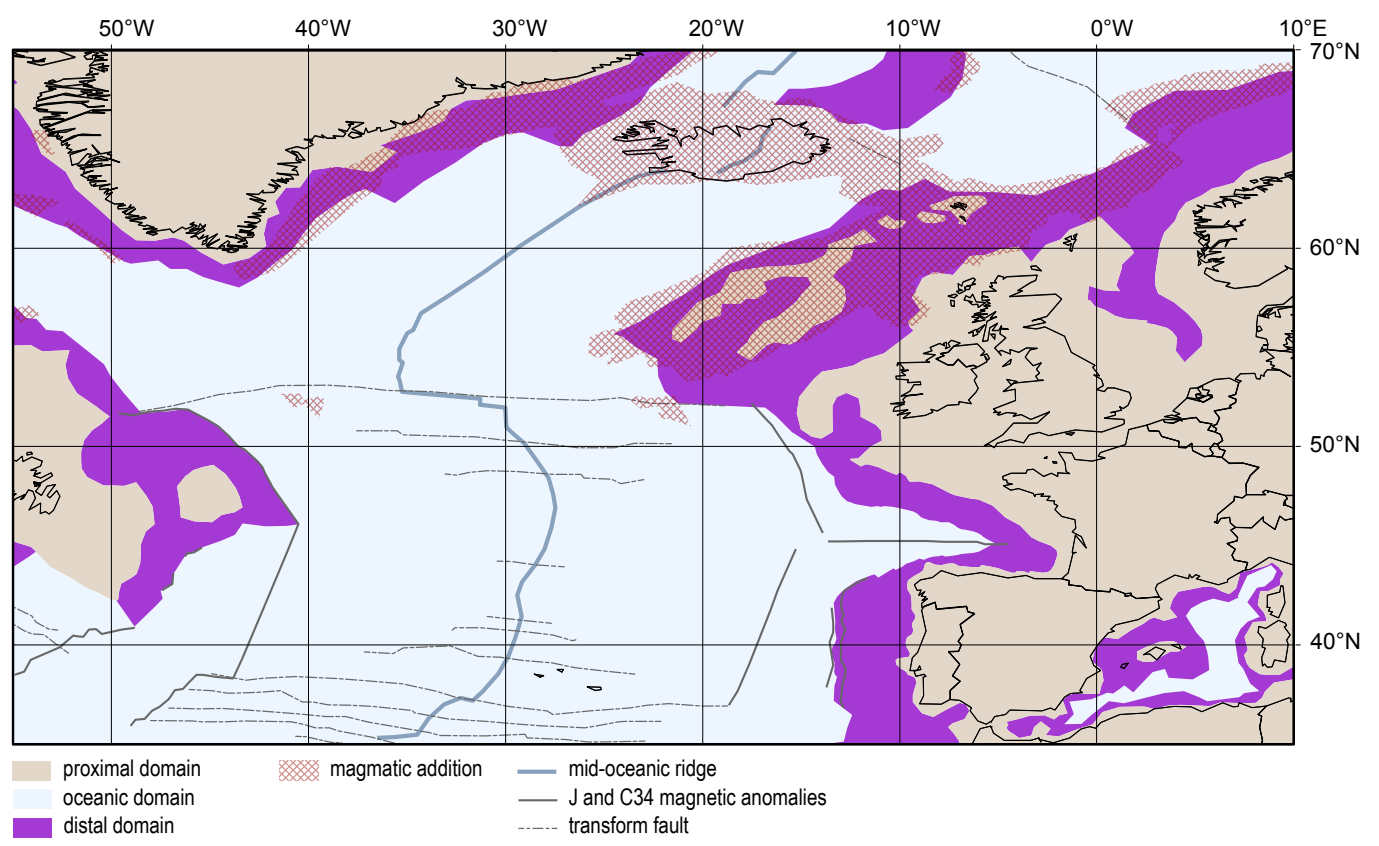

Figure 3: a) Definition of the rift domains used to map the North Atlantic rift system, based on the TGS and LG12 reflection seismic section of the Iberian margin and simplified after Sutra et al. (2013); b) Map of the rift domains and breakup related magmatism along the North Atlantic margins 
$7 \mathrm{~km} / 2 \mathrm{~s}$ TWT thick layer on top of which sediments are deposited passively. As in most places this transition matches with the first magnetic anomaly (Bronner et al., 2011), thus we use the EMAG2 Earth Magnetic Anomaly Grid as a large-scale template to interpolate between seismic sections.

We rely on the work by Tugend et al. (2014) in the Bay of Biscay and Iberian Margin. We use reflection seismic profiles from the BIRPS survey as well as interpretation of seismic reflection and refraction data by White and Smith (2009), Welford et al. (2012), Klingelhöfer et al. (2005), Kimbell et al. (2010), Hopper et al. (2003) and Funck et al. (2008), and crustal thickness compilation by Ziegler and Dèzes (2006) along the Irish-United Kingdom margins. In the Norwegian sector, we build on seismic interpretations by Faleide et al. (2008) and crustal thickness compilation by Ebbing and Olesen (2010). Definition of rift domains in the North Sea as well as in the Mediterranean area is based on the crustal thickness map by Ziegler and Dèzes (2006). We build on the interpretation by Péron-Pinvidic et al. (2013) for the Jan Mayen microcontinent. Along the east-Greenland margin we use refraction seismic models by Hopper et al. (2003) and Korenaga et al. (2000), and use refraction and reflection seismic data published by Louden and Chian (1999) along southwest Greenland. Definition of rift domains in the Baffin Bay area is also based on seismic interpretation by Louden and Chian (1999), as well as on the study by Chalmers and Pulvertaft (2001). Finally, we build on the work by Funck et al. (2003); Hopper et al. (2004); Shillington et al. (2006); Péron-Pinvidic and Manatschal (2010); Sutra et al. (2013) and Welford et al. (2010) in the Newfoundland-Flemish Cap region. Note that the Celtic Sea may have reached the point of necking, but as this hypothesis has not been asserted yet we do not include it in our map.

However, it is important to keep in mind that this approach is only rigorous for magmapoor margins. In the case of extensive magmatic additions as in northern North Atlantic, the architecture of the initial continental crust may be concealed on seismic data as well as in the gravimetric record. Therefore, we display on our map the location of extruded, intruded or underplated magmatic additions (Figure $3 \mathrm{~b}$ ). This compilation is built from the studies by Meyer et al. (2007); Blystad et al. (1995); Lundin and Doré (2011); Gernigon et al. (2012); Storey et al. (2007); White et al. (2003); Clift and Turner (1998) and Chalmers and Pulvertaft (2001). 


\subsection{Rift domains map: highlights}

The map resulting from this compilation is shown on Figure $3 \mathrm{~b}$ and highlights: (1) distal domains are not always associated with lithospheric breakup (e.g. North Sea, Rockall and Hatton Trough, Porcupine Basin and Flemish Pass); (2) the distal domain is comparably wide on both sides of the southern North Atlantic; conversely, the eastern distal domain of the northern North Atlantic is significantly wider than its conjugate and, unlike the latter, it contains ribbons of barely thinned continental crust (Rockall, Hatton and Porcupine banks); (3) the magmatic additions in the northern North Atlantic are broadly limited to the distal domain, in particular their most distal limit usually corresponds to the transition to oceanic crust.

\section{$5 \quad$ Mapping rift timing}

\subsection{Definition}

In the previous section we define rift domains associated with deformation modes. In this section, we aim to date the transition between stretching and necking and the transition between hyperextension / exhumation and seafloor spreading, which correspond to the proximal and distal limit of the distal domain, respectively.

The transition between stretching and necking is a localization process in that, the initially widely distributed extension starts to focus on a few faults, resulting in the abandonment and sealing of the most proximal sedimentary basins (Figure 4 a). This event is recorded by the deposition of the so-called necking unconformity (see Masini et al., 2013) in the proximal domain, which is usually well-imaged on reflection seismic sections as the transition between syn-tectonic / fan shape deposits and passive infill (e.g. right insert in Figure 4 a). In more distal settings, these surfaces often appear as major surfaces of passive onlap onto rotated and truncated strata - e.g. the approximate Base Cretaceous 'Late Cimmerian surface' of the North Atlantic domain, (Erratt et al., 1999).

The transition between hyperextension / exhumation and steady-state seafloor spreading referred to as the lithospheric breakup is also a localization process in the sense that extension via deformation of pre-existing material is replaced by accretion of newly-formed magmatic material. Therefore, this event is also recorded as a transition from syn-tectonic deposits to passive infill, 
comparable to the necking unconformity. Thus, the breakup unconformity is younger than the latter and only exists in the distal domain. Note however that the existence of a unique breakup unconformity recording the onset of seafloor spreading is widely debated, since in several cases lithospheric breakup is pre-dated by the play of successive detachment delocalizing the deformation towards the rift axis, each step being associated with the formation of a discrete 'breakup unconformity' (e.g. Australian northwest shelf, Gillard et al., 2015).

\subsection{Mapping method and limitations}

Because of the scarcity of drilling at deep margins, thus of direct dating, we rely on published data to assign a necking and lithospheric breakup age to each distal domain. It is important to keep in mind that rifting may be polyphase, meaning that several independent extensional events may have succeeded and / or overlapped one another, leading to complex rift histories and associated sedimentary records.

Necking in Iberia-Newfoundland begins at $145 \mathrm{Ma}$ and lithospheric breakup occurs at $112 \mathrm{Ma}$ (Sibuet et al., 2007; Bronner et al., 2011; Sutra et al., 2013), while at $140 \mathrm{Ma}$ and $110 \mathrm{Ma}$, respectively in the Bay of Biscay (Thinon et al., 2003). Necking is late Jurassic - early Cretaceous in east and west Orphan Basin, Rockall Trough Porcupine Basin and Flemish Pass, and late Cretaceous in westernmost Orphan Basin and Labrador Sea (Sibuet et al., 2007). Necking in Hatton Basin is late Jurassic - early Cretaceous (Shannon et al., 1999) and breakup occurs at 53 - 56 Ma (Elliott and Parson, 2008). For rifting between Goban Spur and Flemish Cap, necking is post-Barremian and lithospheric breakup late Albian (De Graciansky et al., 1985). Necking begins during late Lower Cretaceous in Labrador Sea and breakup is dated at $61 \mathrm{Ma}$ (Chalmers and Pulvertaft, 2001; Keen et al., 2012). Necking is Latest Jurassic in the North Sea and MidNorway (Erratt et al., 1999) as well as between Greenland and Jan Mayen (Lundin and Doré, 1997; Melankholina, 2008), while it is Cretaceous along southern Greenland (Péron-Pinvidic et al., 2013). Lithospheric breakup is Eocene between Norway and Greenland and between Norway and Jan Mayen (Talwani and Eldholm, 1977; Roberts et al., 1999; Péron-Pinvidic et al., 2013), while it occurs in late Oligocene between Jan Mayen and Greenland (Melankholina, 2008). 
a)

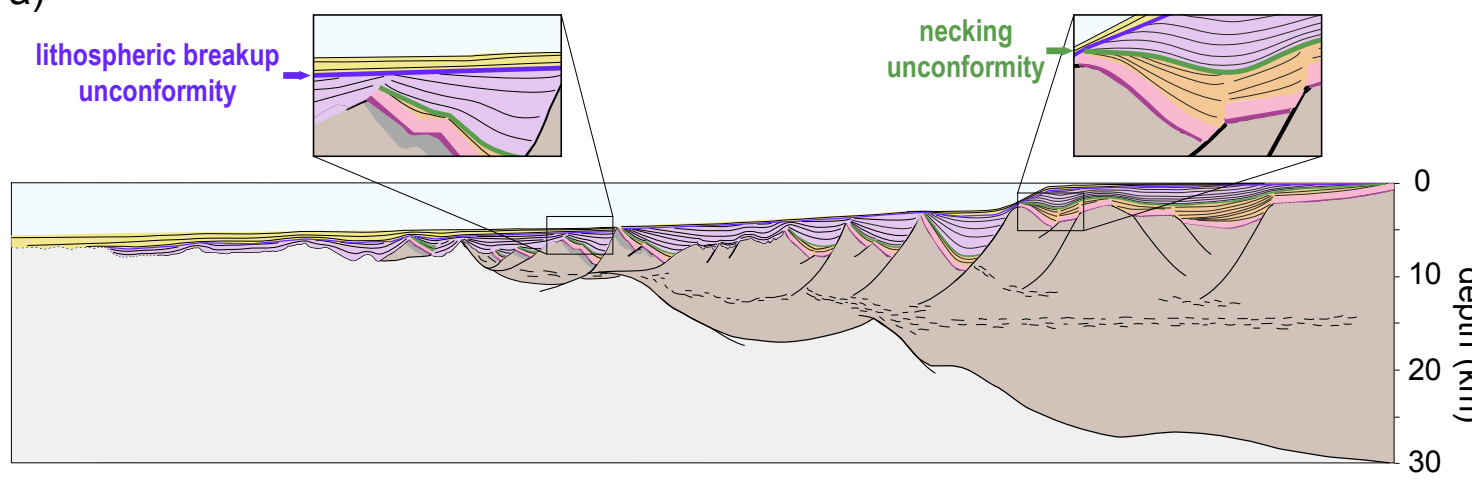

b)

\section{Necking age}

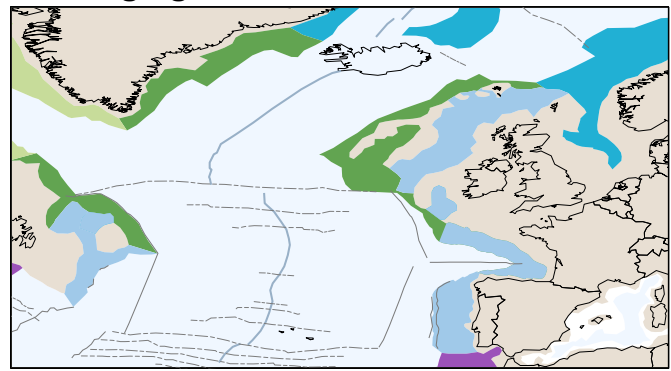

\section{Breakup age}

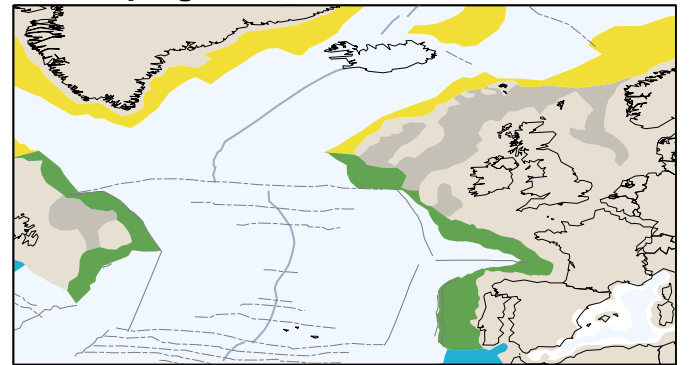

\section{Time lag between necking and breakup}

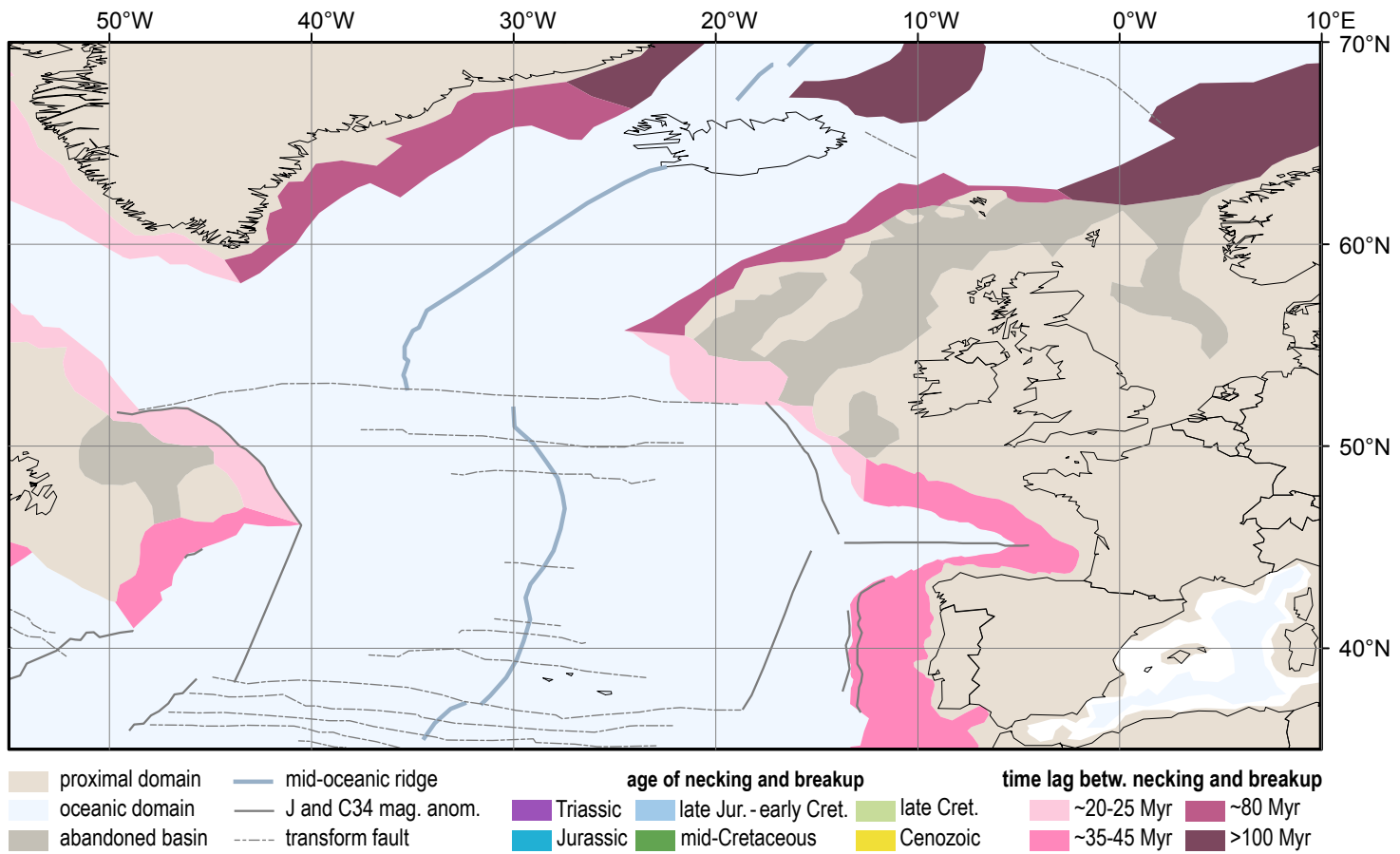

Figure 4: a) Definition of how the two major deformation mode shifts, namely the necking and lithospheric breakup, are recorded in the sedimentary sequence; b) Maps highlighting the timing of necking (top left), lithospheric breakup (top right) and time lag between these two events (bottom) for the North Atlantic rift system 


\subsection{Rift timing maps: highlights}

The map resulting from this compilation is shown on Figure $4 \mathrm{~b}$. It highlights that a phase of necking affected the whole North Atlantic region during the late Jurassic. However, lithospheric breakup occurred earlier in the south (Cretaceous) than in the North (Eocene). This reflects in the significantly longer time lag between necking and lithospheric breakup in northern North Atlantic ( $>80 \mathrm{Myr})$ compared to the south $(<45 \mathrm{Myr})$.

\section{Discussion}

\subsection{Maps analysis and comparison}

Comparison between the orogenic inheritance map and the rift domains map (Figures $2 \mathrm{~b}$ and $3 \mathrm{~b}$, respectively) highlights an abrupt and significant difference in the characteristics of the North Atlantic rift system on each side of the Variscan deformation front. Indeed, the rift cuts through the Caledonian orogenic lithosphere and parallels its structural grain north of the Variscan front, whereas it circumvents the core of the Variscides to the south. Interestingly, within the area affected by both the Caledonides and the Variscides, the orogenic trends relative to each orogen are reactivated at different time of the rifting: the early Triassic stretching phase resulted in the formation of NNE-SSW oriented basins in southern United-Kingdom-Celtic Sea, reactivating Variscan structures, whilst the Caledonian trend manifests only later, during the thinning and exhumation phases.

Moreover, rifting is polyphase and protracted (> $80 \mathrm{Myr})$, marked by the development of a succession of 'failed rift basins' north to the Variscan front. In contrast, the duration of rifting is significantly shorter $(<50 \mathrm{Myr})$ and breakup is achieved within more or less one single episode of lithospheric thinning to the south (Figure $4 \mathrm{~b}$ ).

The amount of breakup related magma is another striking characteristic differentiating the northern from the southern part of the North Atlantic rift system. Indeed, north to the Variscan front breakup is magma-rich, leading to the formation a thicker-than-normal 'transitional oceanic crust' made of Seaward Dipping Reflectors (> $10 \mathrm{~km}$, e.g. White et al. 1992) progressively evolving into a 'normal', steady-state, oceanic crust. In contrast, breakup is magma-poor to the south (Figure $3 \mathrm{~b}$ ). It is interesting to note that, although magmatic additions in northern 
North Atlantic are not concomitant to the formation of the distal domain but are younger since they overlie it, magma-rich systems in this region seem to be characterized by a long time lag between necking and breakup. Therefore, we suggest that, in the case of the North Atlantic rift, protracted and / or polyphase extension may be responsible for, or a prerequisite to, magma-rich breakup. This idea could be tested in other rifted margins globally.

On the other hand, Roberts et al. (1999) described the opening of the North Atlantic in terms of one northward propagating rift terminating in the Porcupine basin and a southward propagating rift terminating in the North Sea (e.g. Figure 4 b). These two extended domains were subsequently abandoned when the two branches of the North Atlantic rift became coalescent offshore United-Kingdom. Here again, the Variscan front is precisely located between these two basins, supporting the proposition that it is a major limit.

Interestingly, the Charlie-Gibbs fracture zone seems to be the continuation offshore of the Variscan deformation front (or of the Rheic suture?) and marks a very sharp limit between magma-rich and magma-poor breakup (Figure 1).

However, regardless of whether it affects Caledonian or Variscan terranes, the North Atlantic rift reactivates the sutures corresponding to former large $(>2,000 \mathrm{~km})$ oceans (e.g. Iapetus and Rheic Oceans), while sutures corresponding to former small $(<500-1,000 \mathrm{~km})$ oceanic basins are little affected (e.g. Tornquist Seaway, Rhenohercynian, Saxothuringian and Medio-European oceanic basins).

\subsection{Areas for further research}

Differences in the architecture, duration and amount of breakup related magmatism in the North Atlantic are dependent on wether the rift system affects Caledonian or Variscan orogenic lithosphere. This observation supports the hypothesis that inheritance significantly impacts subsequent rifting phases. Possible controlling factors include: (1) the thermal state, which depends on the time lag between the last orogeny and the rifting $(\sim 200 \mathrm{Myr}$ for the Caledonides versus $\sim 100$ Myr for the Variscides); (2) the number and size of the oceans involved in the orogen (essentially one large ocean in the case of the Caledonides versus multiple small oceanic basins in the case of the Variscides); and (3) the characteristics of the post-orogenic collapse (purely mechanical in the case of the Caledonides, while associated with significant magmatism in the 
case of the Variscides).

Besides, the contrasting behaviour of the North Atlantic rift relative to suture zones depending on the size of the corresponding former ocean strongly suggests that the pre-orogenic story - in particular the characteristics of intervening subduction(s) - have a major impact on subsequent rifting. Hypotheses to be tested include (1) the impact of the maturity (lithology and thermal state) of the slab; and (2) the duration of the subduction and associated tectonic, magmatic and metasomatic processes such as the existence of a magmatic arc, existence of a back arc basin, enrichment of the mantle by subducted fluids and sediments.

\section{Conclusion}

Throughout this paper we present new large-scale mapping methods driven by observations that highlight the architecture and timing of rift systems, as well as the distribution of firstorder orogenic inheritance. Application of this approach to the North Atlantic rift system and adjacent Caledonian and Variscan orogenic domains shows that: (1) not all rift systems that go beyond necking achieve breakup (e.g. Rockall, Orphan, Porcupine basins); (2) breakup related magmatism is mostly restricted to the distal domain; (3) the North Atlantic rift characteristics differ depending on the type of orogenic lithosphere it affects. In the case of the Caledonides, it cuts through the orogen and parallels its structural grain, has a protracted duration $(>80 \mathrm{Myr})$ and a magmatic breakup. Conversely the rift circumvents the core of the Variscan orogen, its duration is much shorter $(<50 \mathrm{Myr})$ and the breakup is magma-poor; (4) whether or not suture zones are reactivated during the North Atlantic rifting seems to be strongly influenced by the size of the corresponding former ocean: rifts tend to follow sutures resulting from the closure of large $(>2,000 \mathrm{~km})$ oceans, while avoiding these associated to the closure of small $(<500-1,000 \mathrm{~km})$ oceanic basins.

\section{Acknowledgement}

This research was supported by Exxon Mobil in the framework of the project CEIBA. We thank G. Karner and C. Johnson for discussion at several stages of this work. We acknowledge T. Doré and D. Frizon de Lamotte for constructive reviews and helpful comments. 


\section{References}

Andersen, T. B. (1998). Extensional tectonics in the Caledonides of southern Norway, an overview. Tectonophysics, 285:333-351.

Arenas, R., Sánchez Martínez, S., Gerdes, A., Albert, R., Díez Fernández, R., and Andonaegui, P. (2014). Re-interpreting the Devonian ophiolites involved in the Variscan suture: U-Pb and $\mathrm{Lu}-\mathrm{Hf}$ zircon data of the Moeche Ophiolite (Cabo Ortegal Complex, NW Iberia). International Journal of Earth Sciences, 103:1385-1402.

Asher, J., Warren, M., Fox, R., Harding, P., Jeffcoate, G., Jeffcoate, S., et al. (2001). The millennium atlas of butterflies in Britain and Ireland. Oxford University Press.

Ballèvre, M., Bosse, V., Ducassou, C., and Pitra, P. (2009). Palaeozoic history of the Armorican Massif: Models for the tectonic evolution of the suture zones. Comptes Rendus Geoscience, 341:174-201.

Blystad, P., Brekke, H., Færseth, R. B., Larsen, B. T., Skogseid, J., and Tørudbakken, B. (1995). Structural elements of the Norwegian continental shelf. part II: The Norwegian Sea region. Norwegian Petroleum Directorate Bulletin, 8:45.

Bois, C., Pinet, B., and Roure, F. (1989). Dating lower crustal features in France and adjacent areas from deep seismic profiles. IUGG Monograph, pages 17-31.

Bronner, A., Sauter, D., Manatschal, G., Péron-Pinvidic, G., and Munschy, M. (2011). Magmatic breakup as an explanation for magnetic anomalies at magma-poor rifted margins. Nature Geoscience, 4:549-553.

Cederbom, C., Larson, S., Tullborg, E.-L., and Stiberg, J.-P. (2000). Fission track thermochronology applied to Phanerozoic thermotectonic events in central and southern Sweden. Tectonophysics, 316:153-167.

Chalmers, J. A. and Pulvertaft, T. (2001). Development of the continental margins of the Labrador Sea: a review. Geological Society, London, Special Publications, 187(1):77-105.

Chenin, P. and Beaumont, C. (2013). Influence of offset weak zones on the development of rift basins: Activation and abandonment during continental extension and breakup. Journal of Geophysical Research, 118(4):1698-1720.

Clift, P. D. and Turner, J. (1998). Paleogene igneous underplating and subsidence anomalies in the rockall-Faeroe-Shetland area. Marine and Petroleum Geology, 15(3):223-243.

Connors, K. and Pryer, L. (2014). East Coast Magnetic Anomaly: Constraints, models and questions. In 4th Conjugate Margins Conference, pages 49-52.

Dadlez, R., Kowalczewski, Z., and Znosko, J. (2013). Some key problems of the pre-Permian tectonics of Poland. Geological Quarterly, 38(2):169-190. 
De Graciansky, P. C., Poag, C. W., Cunningham, R., Loubere, P., Masson, D. G., Mazzullo, J. M., Montadert, L., Müller, C., Otsuka, K., Reynolds, L. A., Sigal, J., Snyder, S. W., Townsend, H. A., Vaos, S. P., and Waples, D. (1985). The Goban Spur transect: Geologic evolution of a sediment-starved passive continental margin. Geological Society of America Bulletin, 96:58-76.

Doré, T. and Lundin, E. (2015). Research focus: Hyperextended continental margins-knowns and unknowns. Geology, 43(1):95-96.

Dunbar, J. A. and Sawyer, D. S. (1989). How preexisting weaknesses control the style of continental breakup. Journal of Geophysical Research, 94(B6):7278-7292.

Ebbing, J. and Olesen, O. (2010). New compilation of top basement and basement thickness for the Norwegian continental shelf reveals the segmentation of the passive margin system. In Vining, B. A. and Pickering, S. C., editors, Petroleum Geology: from mature basins to new frontiers - Proceedings of the 7th Conference, pages 885-897. The Geological Society, London.

Edel, J. B., Schulmann, K., Skrzypek, E., and Cocherie, A. (2013). Tectonic evolution of the European Variscan belt constrained by palaeomagnetic, structural and anisotropy of magnetic susceptibility data from the Northern Vosges magmatic arc (Eastern France). Journal of the Geological Society, 170:785-804.

Elliott, G. M. and Parson, L. M. (2008). Influence of margin segmentation upon the break-up of the Hatton Bank rifted margin, NE Atlantic. Tectonophysics, 457(3-4):161-176.

Erratt, D., Thomas, G. M., and Wall, G. R. T. (1999). The evolution of the Central North Sea Rift. In Fleet, A. J. and Boldy, S. A. R., editors, Petroleum Geology of Northwest Europe: Proceedings of the 5th Conference, pages 63-82. The Geological Society, London.

Faleide, J. I., Tsikalas, F., Breivik, A. J., Mjelde, R., Ritzmann, O., Engen, O., Wilson, J., and Eldholm, O. (2008). Structure and evolution of the continental margin off Norway and the Barents Sea. Episodes, 31(1):82-91.

Finger, F. and Steyrer, H. (1990). I-type granitoids as indicators of a late Paleozoic convergent ocean-continent margin along the southern flank of the central European Variscan orogen. Geology, 18(12):1207-1210.

Franke, W. (2006). The Variscan orogen in Central Europe: construction and collapse. In Gee, D. G. and Stephenson, R. A., editors, European Lithosphere Dynamics. Geological Society, London, Memoirs 32, pages 333-343. The Geological Society of London.

Franke, W. and Engel, W. (1988). Tectonic settings of synorogenic sedimentation in the Variscan belt of Europe. In Besly, B. M. and Kelling, G., editors, Sedimentation in a synorogenic basin complex: the Upper Carboniferous of Northwest Europe, pages 8-17. Blackie, Glasgow.

Frizon de Lamotte, D., Raulin, C., Mouchot, N., Wrobel-Daveau, J.-C., Blanpied, C., and Ringenbach, J.-C. (2011). The southernmost margin of the Tethys realm during the Mesozoic and Cenozoic: Initial geometry and timing of the inversion processes. Tectonics, 30(3). 
Funck, T., Andersen, M. S., Keser Neish, J., and Dahl-Jensen, T. (2008). A refraction seismic transect from the Faroe Islands to the Hatton-Rockall Basin. Journal of Geophysical Research, 113(B12):B12405.

Funck, T., Hopper, J. R., Larsen, H. C., Louden, K. E., Tucholke, B. E., and Holbrook, W. S. (2003). Crustal structure of the ocean-continent transition at Flemish Cap: Seismic refraction results. Journal of Geophysical Research: Solid Earth (1978-2012), 108(B11).

Gee, D. G., Janak, M., Majka, J., Robinson, P., and van Roermund, H. (2012). Subduction along and within the Baltoscandian margin during closing of the Iapetus Ocean and BalticaLaurentia collision. Lithosphere, 5(2):169-178.

Gernigon, L., Gaina, C., Olesen, O., Ball, P., Péron-Pinvidic, G., and Yamasaki, T. (2012). The Norway Basin revisited: From continental breakup to spreading ridge extinction. Marine and Petroleum Geology, 35:1-19.

Gillard, M., Autin, J., Manatschal, G., Sauter, D., Munschy, M., and Schaming, M. (2015). Tectonomagmatic evolution of the final stages of rifting along the deep conjugate australianantarctic magma-poor rifted margins: Constraints from seismic observations. Tectonics, $34(4): 753-783$.

Hopper, J. R., Dahl-Jensen, T., Holbrook, W. S., Larsen, H. C., Lizarralde, D., Korenaga, J., Kent, G. M., and Kelemen, P. B. (2003). Structure of the SE Greenland margin from seismic reflection and refraction data: Implications for nascent spreading center subsidence and asymmetric crustal accretion during North Atlantic opening. Journal of Geophysical Research, 108(B5):2269.

Hopper, J. R., Funck, T., Tucholke, B. E., Larsen, H. C., Holbrook, W. S., Louden, K. E., Shillington, D., and Lau, H. (2004). Continental breakup and the onset of ultraslow seafloor spreading off Flemish Cap on the Newfoundland rifted margin. Geology, 32(1):93-96.

Huigen, Y. D. and Andriessen, P. A. M. (2004). Thermal effects of Caledonian foreland basin formation, based on fission track analysis applied on basement rocks in central Sweden. Physics and Chemistry of the Earth, 29:683-694.

Jaupart, C. and Mareschal, J. C. (2007). Heat flow and thermal structure of the lithosphere. Treatise on Geophysics, 6:217-251.

Keen, C. E., Dickie, K., and Dehler, S. A. (2012). The volcanic margins of the northern Labrador Sea: Insights to the rifting process. Tectonics, 31(TC1011).

Kimbell, G., Ritchie, J., and Henderson, A. (2010). Three-dimensional gravity and magnetic modelling of the Irish sector of the NE Atlantic margin. Tectonophysics, 486:36-54.

Klingelhöfer, F., Edwards, R. A., Hobbs, R. W., and England, R. W. (2005). Crustal structure of the NE Rockall Trough from wide-angle seismic data modeling. Journal of Geophysical Research, 110(B11):B11105. 
Korenaga, J., Holbrook, W. S., Kent, G. M., Kelemen, P. B., Detrick, R. S., Larsen, H., Hopper, J. R., and Dahl-Jensen, T. (2000). Crustal structure of the southeast Greenland margin from joint refraction and reflection seismic tomography. Journal of Geophysical Research, 105(B9):21,591-21,614.

Larson, S. A., Tullborg, E.-L., Cederbom, C., and Stiberg, J.-P. (1999). Sveconorwegian and Caledonian foreland basins in the Baltic Shield revealed by fission-track thermochronology. Terra Nova, 11(5):210-215.

Lavier, L. L. and Manatschal, G. (2006). A mechanism to thin the continental lithosphere at magma-poor margins. Nature, 440:324-328.

Louden, K. E. and Chian, D. (1999). The deep structure of non-volcanic rifted continental margins. Phil. Trans. R. Soc. London, 357:767-799.

Lundin, E. R. and Doré, A. G. (1997). A tectonic model for the Norwegian passive margin with implications for the NE Atlantic: Early Cretaceous to break-up. Journal of the Geological Society, 154:545-550.

Lundin, E. R. and Doré, A. G. (2011). Hyperextension, serpentinization, and weakening: A new paradigm for rifted margin compressional deformation. Geology, 39(4):347-350.

Manatschal, G., Lavier, L., and Chenin, P. (2015). The role of inheritance in structuring hyperextended rift systems: Some considerations based on observations and numerical modeling. Gondwana Research, 27(1):140-164.

Masini, E., Manatschal, G., and Mohn, G. (2013). The Alpine Tethys rifted margins: Reconciling old and new ideas to understand the stratigraphic architecture of magma-poor rifted margins. Sedimentology, 60:174-196.

Matte, P. (1986). Tectonics and plate tectonics model for the Variscan belt of Europe. Tectonophysics, 126(2):329-374.

Matte, P. (2001). The Variscan collage and orogeny (480- $290 \mathrm{Ma}$ ) and the tectonic definition of the Armorica microplate: a review. Terra Nova, 13:122-128.

Mckerrow, W. S., Mac Niocaill, C., Ahlberg, P. E., Clayton, G., Cleal, C. J., and Eagar, R. M. C. (2000). The late Paleozoic relations between Gondwana and Laurussia. In Franke, W., Haak, V., Oncken, O., and Tanner, D., editors, Orogenic processes: quatification and modelling in the Variscan belt, pages 9-20. The Geological Society, London, Special Publications, London.

Meissner, R. (1999). Terrane accumulation and collapse in central Europe: seismic and rheological constraints. Tectonophysics, 305(1-3):93-107.

Melankholina, E. N. (2008). Tectonotype of volcanic passive margins in the Norwegian-Greenland region. Geotectonics, 42(3):225-244.

Meyer, R., van Wijk, J., and Gernigon, L. (2007). The North Atlantic Igneous Province: A review of models for its formation. In Foulger, G. and Jurdy, D., editors, Plates, plumes, 
and planetary processes: Geological Society of America Special Paper 430, volume 2430, pages 525-552. The Geological Society of America.

Milnes, A., Wennberg, O., Skår, Ø., and Koestler, A. (1997). Contraction, extension and timing in the South Norwegian Caledonides: the Sognefjord transect. Geological Society, London, Special Publications, 121(1):123-148.

Mjelde, R., Breivik, A. J., Raum, T., Mittelstaedt, E., Ito, G., and Faleide, J. I. (2008). Magmatic and tectonic evolution of the North Atlantic. Journal of the Geological Society, London, 165:3142.

Mooney, W. D. and Brocher, T. M. (1987). Coincident seismic reflection/refraction studies of the continental lithosphere: a global review. Geophysical Journal International, 89(1):1-6.

Mosar, J. (2003). Scandinavia-North Atlantic passive margin. Journal of Geophysical Research, 108(B8, 2360).

Müntener, O., Pettke, T., Desmurs, L., Meier, M., and Schaltegger, U. (2004). Refertilization of mantle peridotite in embryonic ocean basins: trace element and $\mathrm{Nd}$ isotopic evidence and implications for crust-mantle relationships. Earth and Planetary Science Letters, 221:293-308.

Murray, C., Scheibner, E., and Walker, R. (1989). Regional geological interpretation of a digital coloured residual Bouguer gravity image of eastern Australia with a wavelength cut-off of $250 \mathrm{~km}$. Australian Journal of Earth Sciences, 36(3):423-449.

Neubauer, F. and Handler, R. (2000). Variscan orogeny in the Eastern Alps and Bohemian Massif: How do these units correlate. Mitt. Österr. Geol. Ges, 92:35-59.

Péron-Pinvidic, G. and Manatschal, G. (2009). The final rifting evolution at deep magma-poor passive margins from Iberia-Newfoundland: a new point of view. International Journal of Earth Sciences.

Péron-Pinvidic, G. and Manatschal, G. (2010). From microcontinents to extensional allochthons: witnesses of how continents rift and break apart? Petroleum Geoscience, 16:189-197.

Péron-Pinvidic, G., Manatschal, G., and Osmundsen, P. T. (2013). Structural comparison of archetypal Atlantic rifted margins: A review of observations and concepts. Marine and Petroleum Geology, 43:21-47.

Petri, B. (2014). Formation et exhumation des granulites permiennes : Établir les conditions prerift et déterminer l'histoire de l'exhumation syn-rift. PhD thesis, Université de Strasbourg.

Piqué, A. and Laville, E. (1996). The central Atlantic rifting: Reactivation of Palaeozoic structures? Journal of Geodynamics, 21(3):235-255.

Rampone, E. (2004). Mantle dynamics during Permo-Mesozoic extension of the Europe-Adria lithosphere: insights from the Ligurian ophiolites. Per. Minearal., 73:215-230. 
Rey, P., Burg, J., and Casey, M. (1997). The Scandinavian Caledonides and their relationship to the Variscan belt Contractional tectonics. In Burg, J.-P. and Ford, M., editors, Orogeny trough time, pages 179-200. Geological Society Special Pubication No. 121, London.

Ring, U. (1994). The influence of preexisting structure on the evolution of the Cenozoic Malawi rift (East African rift system). Tectonics, 13(2):313-326.

Roberts, D. (2003). The Scandinavian Caledonides: event chronology, palaeogeographic settings and likely modern analogues. Tectonophysics, 365:283-299.

Roberts, D. G., Thompson, M., Mitchener, B., Hossack, J., Carmichael, S., and Bjørnseth, H.-M. (1999). Palaeozoic to Tertiary rift and basin dynamics: mid-Norway to the Bay of Biscay - a new context for hydrocarbon prospectivity in the deep water frontier. In Fleet, A. J. and Boldy, S. A. R., editors, Petroleum Geology of Northwest Europe: Proceedings of the 5th Conference, pages 7-40. The Geological Society, London.

Schaltegger, U. and Gebauer, D. (1999). Pre-Alpine geochronology of the Central, Western and Southern Alps. Schweiz. Mineral. Petrogr. Mitt., 79:79-87.

Schuster, R. and Stüwe, K. (2008). Permian metamorphic event in the Alps. Geology, 36(8):603606.

Shannon, P., Jacob, A., O’Reilly, B., Hauserr, F., Readman, P., and Makris, J. (1999). Structural setting, geological development and basin modelling in the Rockall Trough. In Geological Society, London, Petroleum Geology Conference series, volume 5, pages 421-431. Geological Society of London.

Shillington, D. J., Holbrook, W. S., Van Avendonk, H. J., Tucholke, B. E., Hopper, J. R., Louden, K. E., Larsen, H. C., and Nunes, G. T. (2006). Evidence for asymmetric nonvolcanic rifting and slow incipient oceanic accretion from seismic reflection data on the newfoundland margin. Journal of Geophysical Research: Solid Earth (1978-2012), 111(B9).

Sibuet, J., Srivastava, S. P., Enachescu, M., and Karner, G. D. (2007). Early Cretaceous motion of Flemish Cap with respect to North America: implications on the formation of Orphan Basin and SE Flemish Cap - Galicia Bank conjugate margins M25-M0 (Late Jurassic - Early Aptian) extension. In Karner, G. D., Manatschal, G., and Pinhiero, L. M., editors, Imaging, Mapping and Modelling Continental Lithosphere Extension and Breakup, Geological Society, London, Special Publications, 282, pages 59-72. The Geological Society of London.

Sintubin, M., Debacker, T. N., and Van Baelen, H. (2009). Early Palaeozoic orogenic events north of the Rheic suture (Brabant, Ardenne): A review. Comptes Rendus Geoscience, 341(2):156173.

Stephens, W. (1988). Granitoid plutonism in the Caledonian orogen of Europe. Geological Society, London, Special Publications, 38(1):389-403.

Storey, M., Duncan, R. A., and Tegner, C. (2007). Timing and duration of volcanism in the North Atlantic Igneous Province: Implications for geodynamics and links to the Iceland hotspot. Chemical Geology, 241:264-281. 
Sutra, E., Manatschal, G., Mohn, G., and Unternehr, P. (2013). Quantification and restoration of extensional deformation along the Western Iberia and Newfoundland rifted margins. Geochemistry, Geophysics, Geosystems, 14(8):2575-2597.

Talwani, M. and Eldholm, O. (1977). Evolution of the Norwegian-Greenland Sea. Geological Society of America Bulletin, 88:969-999.

The International Gravimetric Bureau, B. G. I. (2012). IAG Geodesist's Handbook. Journal of Geodesy, 86(10).

Thinon, I., Matias, L., Réhault, J. P., Hirn, A., Fidalgo-González, L., and Avedik, F. (2003). Deep structure of the Armorican Basin (Bay of Biscay): a review of Norgasis seismic reflection and refraction data. Journal of the Geological Society of London, 160:99-116.

Timmerman, M. J. (2004). Timing, geodynamic setting and character of Permo-Carboniferous magmatism in the foreland of the Variscan Orogen, NW Europe. Geological Society, London, Special Publications, 223(1):41-74.

Tommasi, A. and Vauchez, A. (2001). Continental rifting parallel to ancient collisional belts: an effect of the mechanical anisotropy of the lithospheric mantle. Earth and Planetary Science Letters, 185:199-210.

Torsvik, T. H. and Rehnström, E. F. (2003). The Tornquist Sea and Baltica-Avalonia docking. Tectonophysics, 362(1):67-82.

Tugend, J., Manatschal, G., Kusznir, N., Masini, E., Mohn, G., and Thinon, I. (2014). Formation and deformation of hyperextended rift systems: Insights from rift domain mapping in the Bay of Biscay-Pyrenees. Tectonics, 33(7):1239-1276.

van Staal, C. R., Barr, S. M., and Murphy, J. B. (2012). Provenance and tectonic evolution of Ganderia: Constraints on the evolution of the Iapetus and Rheic oceans. Geology, 40(11):987990.

von Raumer, J. F., Stampfli, G. M., and Bussy, F. (2003). Gondwana-derived microcontinentsthe constituents of the Variscan and Alpine collisional orogens. Tectonophysics, 365:7-22.

Welford, J., Shannon, P. M., O'Reilly, B. M., and Hall, J. (2012). Comparison of lithosphere structure across the Orphan Basin, Flemish Cap and Irish Atlantic conjugate continental margins from constrained 3D gravity inversions. Journal of the Geological Society, London, pages $1-16$.

Welford, J. K., Shannon, P. M., O'Reilly, B. M., and Hall, J. (2010). Lithospheric density variations and Moho structure of the Irish Atlantic continental margin from constrained 3-D gravity inversion. Geophysical Journal International, 183:79-95.

White, R. S., McKenzie, D., and O’Nions, R. K. (1992). Oceanic crustal thickness from seismic measurements and rare earth element inversions. Journal of Geophysical Research: Solid Earth (1978-2012), 97(B13):19683-19715. 
White, R. S., Smallwood, J. R., Fliedner, M. M., Boslaugh, B., Maresh, J., and Fruehn, J. (2003). Imaging and regional distribution of basalt flows in the Faeroe-Shetland Basin. Geophysical Prospecting, 51:215-231.

White, R. S. and Smith, L. K. (2009). Crustal structure of the Hatton and the conjugate East Greenland rifted volcanic continental margins, NE Atlantic. Journal of Geophysical Research, 114(B2):B02305.

Wilson, J. T. (1966). Did the Atlantic close and then re-open? Nature, 211:676-681.

Withjack, M. O., Schilsche, R. W., and Olsen, P. E. (2012). Development of the passive margin of eastern North America: Mesozoic rifting, igneous activity, and breakup. In Roberts, D. G. and Bally, A. W., editors, Regional Geology and Tectonics: Phanerozoic Rift Systems and Sedimentary Basins: Phanerozoic Rift Systems and Sedimentary Basins, pages 301-335. Elsevier.

Woodcock, N., Soper, N., and Strachan, R. (2007). A Rheic cause for the Acadian deformation in Europe. Journal of the Geological Society, 164(5):1023-1036.

Woodcock, N. and Strachan, R. (2009). The Caledonian Orogeny: a multiple plate collision. Geological history of Britain and Ireland, page 187.

Ziegler, P. A. (1988). Evolution of the Arctic-North Atlantic and the Western Tethys. American Association of Petroleum Geologists Memoir, 43:164-196.

Ziegler, P. A. and Dèzes, P. (2006). Crustal Evolution of Western and Central Europe. In Gee, D. G. and Stephenson, R. A., editors, European Lithosphere Dynamics, pages 43-56. Geological Society, London, Memoir 32. 